\title{
RACJONALNOŚĆ ODROCZONA: POSTSEKULARNE ANTYCYPACJE AMERYKAŃSKIE W MYŚLI GEORGE'A SANTAYANY
}

Katarzyna Kremplewska

Szkoła Nauk Społecznych Polskiej Akademii Nauk

Jako wykładowca na Uniwersytecie Harvarda na początku XX stulecia Santayana był świadkiem sekularyzujących trendów w ramach amerykańskiego życia religijnego. Popularny już w XVIII wieku deizm, a potem liberalne i ultraliberalne ruchy, takie jak unitarianizm, w powiązaniu ze wzrostem dobrobytu i ugruntowaniem się demokracji zmieniły oblicze i ograniczyły wpływy żarliwego purytańskiego protestantyzmu amerykańskich elit. $\mathrm{Na}$ coraz bardziej zróżnicowanym etnicznie i kulturowo obszarze zdobywały zwolenników nowe ruchy religijne oferujące oczyszczające nawrócenie, zwane Nowymi Narodzinami, New Birth. To do nich chętnie odwoływał się William James, analizując odmiany doświadczenia religijnego. Santayanę bardziej interesowała reakcja na sekularyzację w łonie protestantyzmu, zwłaszcza próba reanimacji ortodoksyjnego kalwinizmu, dla której ukuł ironiczna nazwę genteel tradition - „szacownej tradycji” ${ }^{1}$. Samozwańcza arystokracja amerykańska, powołująca się na religijne dziedzictwo Ojców Założycieli, dystansowała się od reszty świata, tworząc swoistą elitarną kastę. Santayana, myśliciel skądinąd utożsamiany z sympatiami konserwatywnymi, wsławił się sarkastyczną krytyką tej „formacji”, przechodząc do historii jako autor serii esejów na temat genteel tradition ${ }^{2}$. Za popularnością szły też

\footnotetext{
${ }^{1}$ Hanna Buczyńska-Garewicz (2011) proponuje thumaczenie „wytworna tradycja”.

${ }^{2}$ Santayana wymyślił i po raz pierwszy użył tej nazwy podczas mowy na Uniwersytecie Berkeley w Kalifornii w 1911. Od tamtej pory genteel tradition weszło do kanonu pojęć w studiach amerykanistycznych. Jest to pojęcie niejednoznaczne. Określa się nim mieszczański, moralizujący trend w kulturze tudzież pewien styl protestanckiej religijności. Oryginalnie było to pojęcie ironicznie opisujące fuzję tzw. kultury wysokiej z plebejską w wykonaniu wykształconej części
} 
uprzedzenia, a w kuluarach nierzadko nazywano go „Lucyferem z Europy” - relatywista, zeświecczonym, katolickim dekadentem.

Kosmopolityzm i europejskie korzenie poparte znakomitym wykształceniem dostarczały Santayanie szerokiej perspektywy, a jedyną niewątpliwą w jego wypadku identyfikacja była autonomia intelektualna. Dystans do rzeczywistości, o której pisał, był albo niezrozumiały, albo niestrawny dla większości amerykańskich intelektualistów, którzy czuli się nade wszystko zaangażowanymi uczestnikami i współtwórcami etosu pracy i wzrastania. Celem tekstu jest wyartykułowanie wówczas niedocenianych, nowatorskich wątków rozważań Santayany na temat religii, laicyzacji i związanej z nimi conditio humana, poprzez umieszczenie ich w postsekularnym kontekście.

\section{/// I.}

W tak zwanych esejach amerykańskich, powstałych w pierwszej dekadzie XX stulecia, filozof wychodzi od cynicznej krytyki nowoczesności, której amerykańskie, konsumpcyjne oblicze określił jako szczególnie drażniące dla umysłów „,nawykłych do innych form doskonałości” (Santayana 1931 |1998: 154). Jednak to sposób przeciwstawienia się związanej z nowoczesnością sekularyzacji okazuje się głównym celem dla ostrza krytyki.

Mimo że doceniał determinację i hart ducha pierwszych amerykańskich purytanów, Santayana był krytyczny wobec typu człowieczeństwa wpisanego w to kulturowe dziedzictwo kalwinizmu, polegającego na - słowami Charlesa Taylora (1989: 215) - „rozpoznaniu własnej nieważności” przez jednostkę i wtopieniu się we wspólnotę pielęgnująca wrogą nieufność wobec inności. Zniesienie podziału na sacrum i profanum, świadomość grzechu, niepewność w kwestii predestynacji i przeświadczenie, że jedynie owoce znojnej pracy nad boskim stworzeniem mogłyby być znakiem łaski w oczach członków wspólnoty, doprowadziły, zdaniem Santayany, do uświęcenia codzienności i uznania materialnego sukcesu za najwyższą cnotę człowieczą. Obserwacja rzeczywistości amerykańskiej nie pozostawiała dlań watpliwości co do społeczno-ekonomicznego postępu, o którym pisał:

rzeczy godne podziwu, może z wyjątkiem ostatniej: dowiadujemy się, że religia ma być instrumentem liberalnego dobrobytu. Ale gdy już ten będzie zapewniony i dysponujemy wszelką wygodą, godnym

\footnotetext{
średniej i wyższej klasy pod egidą religijności i patriotyzmu. Robert Davidoff we wstępie do nowego wydania The Genteel Tradition zauważa, że dziś za genteel należałoby uznać dominującą kulturę liberalna w USA w ogóle. Charles Taylor w The Sources of the Self podkreśla to drugie, religijne znaczenie, prawdopodobnie nieświadomy autorstwa pojęcia. Za Philipem Gravenem, autorem The Protestant Temperament, mówi o trzech historycznych typach amerykańskiego protestantyzmu: ewangelickim, umiarkowanym i „szacownym” (gentee). Ten ostatni wyróżniał się od dwóch pozostałych uzewnętrznioną, zrytualizowaną i skonwencjonalizowaną formą (Taylor 1989: 312).
} 
szacunku zewnętrzem i całkowitą intelektualną wolnością, jakie okazuja się korzyści duchowe? Żadne. Duchowość w tym systemie jest jedynie narzędziem, którego funkcja wypełnia się w realizacji dóbr materialnych. (Santayana 1931|1998: 160)

Już Weber przewidział, jaki koszt przyjdzie ponieść uczestnikom społeczeństw realizujących protestancką wizję świata. Santayana, w dużej mierze zgodnie z Weberem, antycypując pojęcie rozumu instrumentalnego, mówił o ograniczeniu świadomości oraz „dyslokacji rozumu” '. Stosowna do miar i kryteriów nowej rzeczywistości redukcja języka, w którym mówi się o człowieku, oznaczała, że osiagnięty dobrobyt traci znaczenie fundamentu wolności dla rozwoju duchowego, bo kurczy się rzeczywistość, w ramach której autoteliczna duchowość mogłaby być rozwijana. Zatem próba reaktywacji ortodoksji kalwińskiej w obliczu laicyzacji nosiła, jego zdaniem, podwójne znamię hipokryzji - po pierwsze, jako próba powrotu do dosłownej legitymizacji świata przez Biblię, co było według niego nierealne, po drugie, jako wyrzeczenie się własnego udziału w tworzeniu podwalin światopoglądowych dla aktualnej rzeczywistości mentalnej.

Obok protestantyzmu to deizm, z którym od czasów Jeffersona identyfikuje się bardziej „odczarowana” część Ameryki, współtworzył etos sprzyjający myśleniu instrumentalnemu. Poglądy autora Genteel Tradition w tej kwestii znajdują niemal wierne odzwierciedlenie we współczesnych analizach Charlesa Taylora. Kanadyjski filozof pokazuje mariaż Baconowskiego empiryzmu z amerykańskim purytanizmem, jego buntem przeciw tradycji kontynentalnej, poczuciem wyjątkowości i ideą totalnego osobistego zaangażowania, którego „dzieckiem” jest nowa, „proceduralna” racjonalność, w pełni operacyjna w uporządkowanym świecie deizmu. W słowach Taylora o zastapieniu modelu życia kontemplatywnego i poczucia uczestnictwa w boskości ideałem technologii i eupraksii echem odbijaja się zarzuty Santayany pod adresem rodzącej się na przełomie wieków w USA kultury. Zgodni są też co do faktu definitywnego rozejścia się formy życia klas średniej i wyższej z ideałem kalwińskiej pokory i codziennej pobożności (piety), jak też z zasadą introspekcji i interpretacji Lutra. Jak zauważa Hanna Buczyńska-Garewicz (2011: 80), krytykowana przez Santayanę „szacowna tradycja”, która nominalnie stała w opozycji wobec liberalnych laickich kręgów, to w zasadzie „formacja grupy wpływowych rodzin pastorskich, $[\ldots]$ kasta »Brahminów bostońskich«".

\footnotetext{
${ }^{3}$ Dyslokacja rozumu to właśnie jego popadnięcie w funkcjonalny tryb „narzędzia”, do którego dochodzi na przykład w wyniku mitycznego myślenia antropomorfizującego świat natury (Santayana, 1905|1954: 257). Typowe światopoglądy oparte na „przemieszczonym” rozumie to pozytywizm i niemiecka filozofia woli. Mimo różnic jest to koncepcja podobna do instrumentalizacji rozumu według Maxa Horkheimera.
} 
Alternatywa wobec ortodoksyjnych, elitarnych genteels był charyzmatyczny Ralph Waldo Emerson, który w pierwszej połowie XIX stulecia zaproponował „,nowego człowieka” - radykalnego indywidualistę, wolnego od piętna grzechu, naturalnie uduchowionego, stwarzającego siebie i własny świat od podstaw, wyłącznie na gruncie osobistego doświadczenia. Do młodego Santayany przemawiała jego pogarda wobec mrocznej ortodoksji i skostnienia konwencji społecznych, zasadniczo natomiast odrzucił panteizm amerykańskich transcendentalistów. Ich entuzjastyczny optymizm uznał za naiwny, a w dłuższej perspektywie niebezpieczny. Ich filozofia, jak każdy monistyczny system, nie była w stanie docenić i problematyzować dwóch zasadniczych kwestii etycznych: zła i inności. W rezultacie, sądził Santayana, natchniona retoryka musiała ustąpić miejsca instrumentalnemu działaniu. Do tego zreszta - jak zauważa w cytowanej tu pracy Buczyńska-Garewicz - zmierzała myśl dojrzałego Emersona, w którego coraz wyraźniej prometejskiej wizji człowiek kształtuje świat na własne potrzeby. Santayana trafnie ocenił znaczenie Emersona dla kształtu amerykańskiej kultury i zgodnie z jego przewidywaniami unitarianizm, którego ten był adwokatem, doprowadzi do szybkiej laicyzacji we własnych szeregach, pozostając jednocześnie żywą formacja, atrakcyjna jako źródło tożsamości dla agnostyków i ateistów sympatyzujących ze swobodnie pojętą duchowością.

Santayana zatem, jako krytyk kultury, ateista o „śladowych” katolickich sympatiach i adwokat teorii o naturalnym ugruntowaniu ludzkiej duchowości, był surowy zarówno wobec nowoczesności i związanej z nią laicyzacji, jak i wobec prób przeciwstawienia się jej ${ }^{4}$. Nie docenił natomiast nowych, alternatywnych ruchów religijnych, gdyż w przeciwieństwie do Jamesa na religię patrzył przede wszystkim z perspektywy treści niesionych przez stare tradycje intelektualne i ich kulturowe skutki. Eseje amerykańskie wiele wyjaśniają na temat filozoficznych źródeł życia religijnego wykształconych Amerykanów i jego społeczno-kulturowych skutków. Zdolność rzeczowego ukazania ich kontynentalnych korzeni i trafność prognoz stawiają Santayanę wśród czołowych intelektualistów epoki. Może natomiast rozczarowywać brak jakiegokolwiek pozytywnego projektu oraz zdawkowość wypowiedzi, które pozwoliłyby określić, co filozof rozumiał przez duchowość, której zapoznanie zarzucał nowoczesnym formom życia.

\footnotetext{
${ }^{4}$ Szczegółowo na temat stosunku Santayany do katolicyzmu pisze Edward Lovely w najnowszej książce: tenże, George Santayana's Pbilosopby of Religion. His Roman Catholic Influences and Phenomenology, Lexington Books, Plymouth 2012.
} 
Więcej na ten temat dowiadujemy się z jego tekstów filozoficznych powstałych częściowo po rezygnacji z profesury na Harvardzie i osiedleniu się w Europie. Składaja się one na stosunkowo spójna propozycję spojrzenia na religię oraz religijność z połączonej filozoficznej i kulturowo-antropologicznej perspektywy, dla której ontologicznego ugruntowania dostarczy powstałe w latach czterdziestych opus magnum Santayany Realms of Being. Przedstawienie Santayany jako czołowego reprezentanta religijnego naturalizmu wraz z propozycja rehabilitacji tej opcji - jako ponownie atrakcyjnej w XXI wieku - przez Jeremy'ego Stone’a jest ważnym krokiem w „odrabianiu zaległości” w badaniach nad tym myślicielem. Jednak perspektywa naturalizmu wydaje się wąska wobec eklektyzmu tego filozofa. Już Dewey zauważył, że Santayana „łamie kręgosłup” naturalizmu z racji swojego metafizycznego języka (Stone 2008: 124). Zaproponowane w dalszej części postsekularne asocjacje moga stanowić przyczynek do dyskusji nad Santayanowskim myśleniem o religii.

\section{/// II.}

„Wyobrażeniowa symbolika życia rozumu”, „aplikowalna fikcja” posługująca się pojęciami „objawienia” i „iluminacji” jako synonimami rozumienia zapośredniczonego w życiu wyobraźni umiejscowionej w pewnej tradycji - takie ujęcie nie odbiera religii jej prawdy ani ważności; przeciwnie, jej status jest szczególny, jako że „ma cały czas i doświadczenie za naturalny przedmiot i wszelkie możliwości bycia za swój ostateczny temat" (Santayana 1900|1936a: 9-11). Religia symbolicznie wyraża ludzka prawdę wynikająca z niekończącej się hermeneutycznej próby konstrukcji sensu na podstawie śladów zawsze już byłego doświadczenia uwikłania egzystencjalnego i w oczekiwaniu na to, co jeszcze nieznane. Odwołując się do znaczeń proponowanych przez Kołakowskiego: religia jako mit jest dowodem metafizycznej potrzeby i próbą uchwycenia niewyrażalnego naukowo marginesu wyjątkowości człowieka, który pozwala mówić o nim jako o członku pewnej wspólnoty. Przygodność i historyczność egzystencji, naturalne ograniczenia i specyfika ludzkiego poznania przez reprezentację stawiają człowieka w sytuacji „przymusowego” wytwórcy kultury. Religia jest wyrazem wysiłku interpretacyjnego i podtrzymująca nadzieję projekcja wyobrażonego najwyższego dobra.

Taki sposób ujęcia tematu sprawił, że Santayana bywał interesujący zarówno dla współczesnej antropologii kulturowej, jak i pewnych, 
inspirujących się hermeneutyką trendów refleksji socjologicznej ${ }^{5}$. Nie będzie nadużyciem wskazanie na kilka podobieństw w ujęciu Santayany i Petera Bergera, poczynając od dialektycznego procesu wytwarzania, obiektywizacji i ponownego, transformującego przyswajania sobie kultury w ramach stwarzania świata przez bezradnego i „niewykończonego” człowieka. Niestabilny i niewyspecjalizowany u Bergera, a u Santayany obarczony tragiczna nieadekwatnością poznania, związaną z projekcją typowo ludzkiej, „sentymentalnej” perspektywy czasowej na dynamiczna rzeczywistość, człowiek jest plastyczny i zdany na świat, a „świat”, którego jest współtwórca, pozostaje zawsze niedomknięty. Transcendencja własnej jednostkowości sytuuje go we wzajemnej relacji stwarzania ze światem. Religia, wynik tego procesu mediacji, jako część kultury jest zatem, z jednej strony, mechanizmem przetrwania, z drugiej - rękojmią człowieczeństwa.

Dalsze porównanie tych teorii nieuchronnie prowadzi do ujawnienia wielu mówiących różnic. Socjolog decyduje się na perspektywę człowieka jako „produktu” społeczeństwa; filozof, choć nie zaprzeczy zasadności określenia zwierze społeczne, pozostanie przy perspektywie indywidualistycznej jako bardziej pierwotnej. Człowiek jest społeczny z perspektywy zewnętrznego obserwatora i zobiektywizowanej już kultury; z perspektywy doświadczenia i budowy sensu natomiast pozostaje zawsze unikalnym ,ja”. Moralność, której nośnikiem jest religia, przestaje być sloganem przede wszystkim z punktu widzenia subiektywnego doświadczenia relacji, a pojęcie „zła” domaga się artykulacji najpierw ze względu na egzystencję.

Berger również docenia potrzebę podejmowania perspektywy indywiduum choćby ze względów heurystycznych. Gdy człowiek „,wynajduje język i spostrzega, że zarówno jego mowa, jak i myśli zdominowane są przez jego gramatykę", uświadomienie sobie rozróżnienia między tym, co „się” mówi, a tym, co mówię ,ja”, oraz jak te mowy się do siebie maja, leży w żywotnym interesie jednostki (Berger 1969: 9). Obszar nieprzekładalnej na zbiorowość indywidualności jest kluczowy dla dynamiki całego procesu. Kultura, która zapoznaje znaczenie indywidualizmu, utrudnia takie rozróżnienie za cenę szeroko omawianej przez Bergera alienacji (1969: 85-86).

Jednak tylko perspektywa społeczna uzasadnia teorię Bergera religijnej legitymizacji świata jako „oczywistości” dla wspólnoty oraz struktur wiarygodności warunkujących przetrwanie tejże religii. Teoria ta zdaje się z góry obarczona znamieniem alienacji, a na jej gruncie zmiany w świadomości ludzkiej w kierunku wzmacniania subiektywności nieuchronnie staną się

\footnotetext{
${ }^{5}$ Po teksty Santayany sięgali między innymi: Clifford Geertz, Ervin Goffman, Alfred Schütz, Walter Lippman.
} 
częścią zjawiska sekularyzacji. Co prawda Berger pokazuje, że laicyzacja, obejmująca cała rzeczywistość społeczną sferą profanum, pozostawia pewne enklawy, takie jak najbliższa rodzina, poza sferą swych wpływów, zdaje się to jednak tylko przygodnym faktem. Nawet gdy dochodzi do wniosku, że ludzkość nie może obyć się bez teodycei i poszukiwania remedium na podstawowe egzystencjalne lęki, to na gruncie jego definicji religii nic nie stoi na przeszkodzie całkowitej sekularyzacji świadomości jako kolejnego etapu agonii Boga.

Santayanie blisko do „,weberowskich” poglądów Bergera co do społeczno-ekonomicznego i kulturowego podłoża laicyzacji życia publicznego, zwłaszcza w kontekście protestantyzmu, gdzie najszybciej upada wyjaśniająca i światopoglądowa funkcja religii. Natomiast przyjęcie przez niego indywidualnego podmiotu o naturalnie ugruntowanej duchowości za punkt wyjścia sprawia, że „koniec religii” nie jest ani definitywny, ani dosłowny, bowiem to świadomość i wyobraźnia, korelujące z rzeczywistością w jej aspekcie możliwości, są żywym źródłem sacrum. To poszukiwanie noetycznych korzeni religijności, nawiązujące do Platona, Augustyna i Kanta, można uznać za postsekularny akcent, stawiający Santayanę blisko myślicieli odczytujących sekularyzację jako fazę tkwiącej w samym sercu chrześcijaństwa humanizacji, a jednocześnie odróżniający go zarówno od redukcyjnych, kompensacyjno-projekcyjnych, jak też stricte społecznych ujęć. Jako krytyk kultury natomiast Santayana jest żywo zainteresowany faktem, że długofalowe oddziaływanie doktryn decyduje o kształcie i, stylu” tejże humanizacji ${ }^{6}$.

Pomimo indywidualistycznej perspektywy u Santayany nie brak też odwołań do wspólnotowego charakteru tradycji jako nośnika sensu i wartości. Hermeneutyczny rys tej myśli polega na dostrzeżeniu możliwości potraktowania tradycji religijnej jako źródła mądrości dla pewnej wspólnoty interpretacyjnej, nawet gdy jej członkowie nie przyjmują już jej treści za wyjaśniająca „obiektywna” rzeczywistość, innymi słowy wtedy, gdy dezaktualizują się lub ulegają metaforyzacji legitymizacja świata i struktury wiarygodności w rozumieniu Bergera ${ }^{7}$.

W tym momencie warto przywołać postać nauczyciela i kolegi Santayany z Harvardu, którego Charles Taylor zaliczył w poczet postsekularnych antycypacji - Williama Jamesa. Mimo że Santayana polemizował z metoda

\footnotetext{
${ }^{6} \mathrm{O}$ tym mowa zarówno w tzw. esejach amerykańskich, jak i znakomitej pracy z 1915 roku German mind: a philosophical diagnosis.

${ }^{7}$ Jednocześnie trzeba zaznaczyć, że Santayana był sceptyczny co do możliwości powszechnego zaangażowania ludzi we wspólnotę interpretacyjna. W tradycji amerykańskiej istotna była i pozostaje rola tzw. public intellectuals - wykonujących pracę interpretacji „za” większość.
} 
i tezami pracy Jamesa o doświadczeniu religijnym, trudno oprzeć się wrażeniu, że w kilku kwestiach ich poglądy brzmią niemal identycznie. Lączył ich antydogmatyzm światopoglądowy, w tym niechęć do wspomnianej genteel tradition, pluralizm i emfaza na doświadczenie egzystencji jako katalizator religijności. Zainteresowanie unikalnością ludzkiej świadomości i sprzeciw wobec pozytywistycznych teorii człowieka jako „produktu” społeczeństwa, które zdawały się odgrywać rolę samospełniających się przepowiedni, poprzedzały bardziej radykalne XX-wieczne ujęcia kontynentalne, takie jak heideggerowskie Dasein. Santayana i James, każdy na swój sposób, unaocznili dwa istotne dla rozumienia sekularyzacji fakty: po pierwsze, że egzystencja koncentruje się wokół idiosynkratycznego świata indywidualnej świadomości; po drugie, że ten świat nie wyrasta ani z refleksyjnego, spekulatywnego Cogito, ani z obiektywnej rzeczywistości społecznej, ale z bardziej źródłowych „obszarów” doświadczenia. Fakt, że mówili o religii innym językiem, nie powinien przesłaniać owych fundamentalnych podobieństw.

Obaj skłonni byli utrzymać pojęcie „natury ludzkiej” i niefilozoficzne założenie tragicznej kondycji człowieczej oraz przyznać pierwszeństwo ludzkiemu moralnemu impulsowi sprzeciwu wobec krzywdy i zła przed czysto teoretycznym i spekulatywnym podejściem. Przyznali doświadczeniu egzystencji godność korekty, jeśli nie weryfikacji filozoficznych opisów rzeczywistości. Można więc powiedzieć, że uwzględniali to, co język psychoanalizy nazywa trauma. Zgadzali się co do tego, że „najbardziej opresyjnym z systemów jest system optymistyczny” (Santayana 1936b: 291), który wbrew empirii nie przyznaje cierpieniu i złu należnej im wagi ${ }^{8}$. James, radykalny empirysta, poszukuje pre-teoretycznego doświadczenia. Santayana przekracza zarówno empiryzm, jak i pragmatyzm, który uważa za metodę raczej niż doktrynę, w poszukiwaniu ontologicznego i kulturowego języka dla opisu relacji pomiędzy doświadczeniem egzystencjalnym a światem idei i wyobrażeń religijnych.

W Varieties of Religious Experience czytamy, że racjonalistyczne doktryny oświeceniowe - deizm, idealizm i monizm - oraz inspirujący się nimi ultraliberalny protestantyzm nie sa w stanie sprostać zadaniu artykulacji zła, które w ich ramach podlega racjonalizacji (James 1902: 99). Santayana pod wpływem Jamesa uczynił tę dyskusję punktem wyjścia dla własnej filozofii kultury. Krytykuje ujednolicające, monistyczne ujęcia rzeczywistości oraz egotystyczne modele zdenaturalizowanej podmiotowości. Stawką są

${ }^{8}$ James napisze, że „przecież nawet optymista Goethe musiał przyznać, że jego życie było pasmem cierpień” (1902|2004: 103). 
dlań kulturowe i etyczne konsekwencje - „typ” człowieczeństwa i forma życia, która z nim się łączy ${ }^{9}$. W kontekście tej stronniczej, bo opartej na pewnych sympatiach, choć ze wszech miar interesującej krytyki Santayanę zajmował problem teodycei, nieunikniony w doktrynach, takich jak deizm, wyrastający na jego gruncie panteizm, spinozjański racjonalizm czy materializm dialektyczny.

Istnienie zła, a jeśli zło jest odczuwane, to istnieje, bo doświadczenie to jego locus, dowodzi tego, że jakaś nieprawidłowość wdarła się do „planu bożego”. [...] Jeśli nasza wierność dobru, która jest warunkiem możliwości racjonalności, ma zachować ważność, [...] musimy dopuścić do głosu, choćby w minimalnym zakresie, zasadę, która nie jest racjonalna. Tąaracjonalną zasadą może być inercja materii, przypadkowe zbłądzenie woli, ostateczny konflikt interesów. Jakoś ten element oporu wobec racjonalności musi być wprowadzony [...] należy stworzyć ideę racjonalności różną od pojęcia bytu. Nie można dłużej, w chórze z optymistami, mówić, że realne to racjonalne i vice versa. Chcemy bowiem wprowadzić rozróżnienie, by pozostać lojalnymi wobec dobra. [...] To, co zwiemy praktyczną lub hebrajską racjonalnością, zdradza w najprostszy możliwy sposób, że rozum jest przede wszystkim funkcją ludzkiej natury. Rozum obecny jest w świecie tak długo, jak długo wspiera życia, które go generuja. (Santayana 1905|1954: 247-248)

Naturalne ugruntowanie i zasada pragmatycznie ujętej racjonalności, która jednakowoż transcenduje partykularność interesów ku lojalności wobec dobru, unikając popadnięcia w instrumentalizm, warunkuja praktyczną religijność - najbardziej codzienną manifestację udziału ludzkiego doświadczenia świata w ontologicznej sferze ducha ${ }^{10}$.

\section{/// III.}

W pracy The Life of Reason filozof proponuje klasyfikację faz rozwoju kultury, które nazywa „systemami moralnymi”, przyjmując za kryterium dynamikę racjonalność - religia. Ruch myślenia po kontinuum, którego krańce wyznacza z jednej strony światopogląd mityczny, z drugiej - czysta

\footnotetext{
${ }^{9}$ I tak na przykład emfaza na element rezygnacji i zaniechania jako wyraz religijnej indywidualności to jedna z analogii ujęcia Santayany z koncepcją innego krytyka kultury - Georga Simmela, przedstawioną między innymi w jego interpretacji postaci Goethego w pracy Goethe z 1923 roku.

${ }^{10}$ Systematyczny podział rzeczywistości na ontologiczne sfery materii, esencji, ducha i prawdy został wprowadzony w pracy Realms of Being.
} 
racjonalność, dialektycznie przechodzi przez trzy fazy: preracjonalna, racjonalną i postracjonalna. Religijność należy więc do procesu myślenia, to zaś ,jest sposobem życia, i to tym najbardziej witalnym" (Santayana 1936b: 287). W każdej z faz pojawiają się pewne typowe światopoglądy, a w ich ramach różne typy religijności i teodycee ${ }^{11}$.

Człowiek Zachodu dąży do pełni racjonalności w nadziei na dobre życie. W tym paradygmacie typowym dla judeochrześcijanskiej tradycji żywa i dynamiczna religia ma zdolność reprezentowania i wspierania człowieczego wysiłku osiagnnięcia sensownego istnienia we wspólnocie w ramach wypracowanego systemu wartości. W fazie preracjonalnej, egzemplifikowanej przez kulty pogańskie i wczesne greckie i egipskie wierzenia, codzienne doświadczenie życiowe funduje moralność, a nadany jej wyraz religijny odpowiada bezpośrednio poznawczym i emocjonalnym potrzebom ludzkim. Religia i mitologia są tożsame, zaklinają rzeczywistość, nadając jej magiczny sens i wyjaśniając bieg rzeczy w naturze i społeczności. Mit, będący zarazem kodem moralnym, jest obiektywizacją najbardziej intuicyjnej etyki, nieświadomej własnego fanatyzmu i nieakceptującej inności. Przejście ku racjonalnej autorefleksji nie dzieje się automatycznie, by stać się faktem, wymaga sprzyjających warunków ekonomicznych i kulturowych, a także - spotkania Innego.

Gdy zależność rozumu od impulsu słabnie, zmienia się relacja myślenia do doświadczenia, a moralność od intuicyjnej ciąży ku racjonalnej. Judaizm, zdaniem Santayany, dokonał spektakularnego kroku w tym kierunku, zakładając, że zdyscyplinowane zachowanie prowadzi do poprawy egzystencji, w wyniku czego członkowie wspólnoty stali się „odporni i zdolni przetrwać w swojej prawomyślności wobec każdej przeciwności losu” (Santayana 1905|1954: 449). Skarykaturyzowany przez Nietzschego sokratejski homo theoreticus to otwarcie na iluminację przez sztukę zadawania pytań, również w sensie kwestionowania, otwierającego nowe przestrzenie przed oczyma rozumu. Jednak czysta spekulacja, intelektualna gra, niezakorzeniona $\mathrm{w}$ tradycji, nie stawia już prawdziwych pytań i nie służy życiu, ale wyradza się w wyrafinowane, totalizujące wizje o imponującej architekturze. Towarzyszy temu opaczne pojmowanie przez rozum swojego

\footnotetext{
${ }^{11}$ Berger również stosuje kryterium „stopnia racjonalności” w swojej ocenie światopoglądów religijnych, a konkretnie teodycei (54). Ma jednak na myśli raczej stopień, w jakim religie są w stanie zracjonalizować przekraczającą jednostkę rzeczywistość, podczas gdy Santayana podchodzi do tematu stricte filozoficznie, mając na myśli dwie tendencje myślenia jako takiego - mityczną i racjonalną. Łączy ich natomiast założenie ,genetycznej” ludzkiej racjonalności, ukierunkowanej na przeżycie i wynegocjowanie optymalnej pozycji człowieka w świecie. Racjonalność odgrywała również kluczową rolę w analizach historii religii Maxa Webera.
} 
celu jako ,pewności”. To dlatego, zdaniem Santayany, grecki intelekt w swojej szczytowej formie, jaką osiaga u Platona, który zresztą doskonale rozumiał, że stawką myślenia jest zbawienie duszy, przekształcał się w wizje, które choć „zbliżały się bliżej niż jakiekolwiek preracjonalne światopoglądy do tego, co rozum mógłby zaakceptować, ostatecznie okazały się mniej użyteczne od tych pierwszych w przybliżaniu racjonalności do celu" (Santayana 1905|1954: 449). Nie przypadkowo wielkie monoteistyczne religie, silnie naznaczone preracjonalnym ,przeczuciem” kondycji i natury ludzkiej, były bardziej skuteczne w formowaniu modeli racjonalnej moralności służącej przetrwaniu i dobremu życiu.

Refleksyjne wznoszenie się racjonalności ponad partykularność interesów i ku zaakceptowaniu innych wizji świata jest jednoznaczne z porzuceniem dogmatu i odczarowaniem. Jednak, gdy na mocy uniwersalistycznych ambicji rozum wyrzeka się swych naturalnych korzeni, demitologizacja kończy się, zdaniem Santayany - jak zauważyli potem Adorno i Horkheimer popadnięciem w nowy mit, mit bezinteresownego rozumu. Ochroną przed taką „dyslokacją" rozumu może okazać się dynamiczna, reinterpretująca kontynuacja pewnej tradycji. Oczywiście jest to ogólnik, ale w jego ramach możliwe jest szerokie spektrum postaw zaangażowania. Santayana, ateista i kosmopolita, nie porzucił przekonania, że tradycja chroni nie tylko zdrowy rozsądek i poczytalność, ale daje możliwość „myślącego” zabrania głosu w jakiejkolwiek dyskusji. Jednoznacznie przeciwny mitowi powrotu do preracjonalności, sądził jednocześnie, że obecność preracjonalnych motywów w tradycyjnych religiach może być „kołem ratunkowym” dla myślenia, gdy czysty intelekt zawodzi na polu empirycznym, a wysokie wymagania ideału pewności poznania sa nierealistyczne w obliczu zależności od materii, gdzie „racjonalne życie dotyka irracjonalności zarówno na obrzeżach, jak i w samym sercu" (Santayana 1905|1954: 455). W ujęciu Santayany, które John Lachs nazwał „rzetelną filozofią działania”, ideałem racjonalności wspierającej życie byłby wrażliwy punkt equilibrium na kontinuum między impulsem a refleksja, prawdopodobnie najbardziej zbliżony do opartej na cnotach etyki arystotelejskiej, jako że ta, przyjmując pojedyncze, relacyjne, rozumne życie za locus etyczności, a jego dobro za cel w sobie, otwierała drogę do rozwoju duchowego.

Santayana był zatem sceptyczny wobec możliwości trwałego konsensu opartego na bezinteresownym intelekcie - postulatu wywodzacego się z sofistyki antycznej i odradzającego się w różnych przebraniach historycznych. Za jądro sofizmatu uważał mit przejrzystości komunikacji, „ignorowanie intencji ṡywego momentu, przyjęcie, że nic innego, żaden inny, 
nieuświadomiony czynnik poza danym człowiekiem [w jego pełnej świadomości] w danym momencie jest jednocześnie tematem, standardem, jak i źródłem własnego sądu" (Santayana 1905|1954: 457). Wynika z tego, że indywidualizm myemancypowany, pod którym się podpisywał, to tyle, co wyemancypowany od dwóch skrajnych idei: radykalnej emancypacji rozumu z jednej strony i powrotu do preracjonalnej bezpośredniości z drugiej. W jej miejsce pojawia się inny styl emancypacji - taki, który dopuszcza przyznanie, że „iluzje graja istotną rolę w moralnej integralności. Wyobraźnia bywa bardziej skuteczna w osiaganiu istoty rzeczy i znaczenia doświadczenia od inteligencji” (Santayana 1905|1954: 451).

\section{/// IV.}

Trzecia, postracjonalna faza myślenia to ponowne „odkrycie” religii w obliczu rozczarowania odczarowaniem. Umysł refleksyjnie i bez obaw daje się prowadzić wyobraźni przez żywotną „fikcję” zorganizowaną w promieniu pewnej tradycji, a natura jej prawdy staje się coraz jaśniejsza. To w tym kontekście Santayana mawiał, że religia, jako deklaracja wyboru pewnej perspektywy, jest porównywalna z zaangażowaniem w twórczość poetycka. Postracjonalność niesie w sobie elementy wszystkich trzech faz - preracjonalną intuicyjność, racjonalne dążenie do dobra i postracjonalna, i refleksyjną zdolność rezygnacji z czegoś na rzecz czegoś innego. Doktryny z przewaga postracjonalnego „sentymentu” - epikureizm, stoicyzm i chrześcijaństwo - łączą się w „krytyce wszelkiego doświadczenia” (Santayana 1905|1954: 467). Warto uzupełnić uwagi Santayany o dokonane przez Charlesa Taylora rozróżnienie między rezygnacją w stylu stoickim, gdzie rezygnuje się z dóbr, które utraciwszy status dóbr, są marnościa, a rezygnacją chrześcijańska, gdzie ogranicza się korzystanie z rzeczywistych dóbr w imię dóbr innej rangi. Samowyrzeczenie chrześcijańskie ma sens woluntarystyczny, augustiański. Wyraża pochodząca z doświadczenia wiedzę o nicości, która - z perspektywy duchowej - wieńczy pełne zaangażowanie w pogoń za doczesnymi dobrami, wiedzę praktyczną z punktu widzenia niezbywalnej nadziei na przyszłe dobro i doskonałość. Obok codziennej pobożności, piety, emocjonalnej zasady powszedniego wysiłku, zostaje wprowadzona wyobrażeniowa zasada „duplikacji świata”. Dlatego Santayana określał wiarę religijna w fazie postracjonalnej jako „drugie życie”, second life, które nie jest iluzją ani opium, ale odnosi się do pewnej sfery rzeczywistości doświadczenia.

Epikureizm, zwiastun postracjonalności, „promował zaświaty bez przesądów i szczęście bez iluzji [...], zaznaczając pierwszy moment zatrzymania wycofującej się racjonalności”' (Santayana 1905|1954: 472). Takie 
doktryny są jednak nietrwałe za sprawą pominięcia dwóch zasad „ludzkiej natury" - woli i nadziei. Zdaniem Santayany każdy światopogląd bez wizji zbawienia, oparty na „kulcie tego, co jest”, szykuje grunt pod nowe, niebezpieczne mitologie, oparte na manipulacji pojęciami. Odmówienie realności pojęciom „ludzkiej natury” i „kondycji ludzkiej”, wyraźne zarówno w panteistycznych wizjach świata, jak i pozytywistycznej redukcji, okazuje się „wykonalne pod warunkiem, że owa [natura ludzka] zostanie na mocy nowej mitologicznej reprezentacji ukazana jako nienaturalna" (Santayana 1905|1954: 473-474).

Chrześcijaństwo swojemu eklektyzmowi i wewnętrznemu napięciu zawdzięcza elastyczną strukturę, respektująca zarówno ludzką kondycję, jak i naturę człowieka, która może się realizować przez mnogość możliwych postaw. Historycznie wyraziło się to $\mathrm{w}$ tendencji do rozgałęziania się chrześcijaństwa w dwa przeciwne typy, będące własnymi zwierciadlanymi odbiciami. Oryginalna wewnętrzna pobożność, esoteric piety, przechodzi bądź w preracjonalny pozytywizm, bądź postracjonalny mistycyzm. Santayana rozumie pierwszy jako codzienne życie i najzwyklejsze aktywności wyrażajace niewyrażalną miłość, drugi zaś - powstrzymanie się od aktywności na rzecz nicości jako jedynego możliwego wyrazu niewyrażalnego. Postawy odbijają się w sobie nawzajem: mistyczna nicość ujawnia to, co przemilczane w codziennej krzątaninie, ta zaś wyraża miłość, w imię której wszystkiego wyrzeka się mistyk.

Praktyka dążenia do zbawienia przybiera odpowiednio bądź pierwotny charakter wewnętrznego skupienia na ideale miłości lub doskonałości, bądź też wtórny charakter, w którym źródło sacrum jest zewnętrze i zobiektywizowane. Ta druga tendencja szybko prowadzi do oświeconej dekonstrukcji i uznania religii za ułudę. Pierwsza - umożliwia pielęgnowanie zinternalizowanej boskości, ale też może stać się ostoją eskapizmu.

„Podwójne serce postracjonalnego chrześcijaństwa oznacza zatem syntezę preracjonalnego hebrajskiego pragnienia ziemi obiecanej z postracjonalnym duchem rezygnacji, odniesioną do greckiej antropologii, wrysowanej w racjonalny, z pragmatycznego punktu widzenia, projekt eschatologiczny. Nawet gdy jako dogmat chrześcijaństwo traci na aktualności, jako tradycja, język i matryca moralna nadal może pełnić swoją funkcję. Jest jednocześnie stare i nowe, wyobrażeniowe i realistyczne, apelujące do serca i rozumu, uzasadniające zarówno sceptycyzm, jak i nadzieję, w myśl sugestii, że ziemskie życie, nawet jeśli próżne jako doświadczenie, uzasadnia się jako próba”. (Santayana 1905|1954: 475).

Chrześcijaństwo jest więc systemem odroczonego racjonalizmu, racjonalizmu „przeciętego” wizją nadnaturalnych warunków możliwości 
szczęścia. Jego zasadą moralna jest rozum - jedyna zasada, jaka istnieje; jego motywem - impuls i naturalna nadzieja, by być i być szczęśliwym. Chrześcijaństwo zaledwie odnawia i ponownie wprowadza te uniwersalne prawidła tuż po pierwszym rozczarowaniu i pierwszym najściu rozpaczy, otwierając nowe perspektywy doskonałości, nowa jakość i miarę sukcesu. Chrześcijańskie pole działania jest światem łaski otaczającym świat natury, miejscem wydarzania się zmian i przemijania wartości i ich znaczeń w ramach jednego kodu. (Santayana 1905| 1954: 476)

Uniwersalność tego kodu musiała korelować z czymś pierwotnym i niezmiennym w czlowieku. Stąd zarówno u Santayany, jak i u Jamesa spotykamy pojęcie „ludzkiej natury” i uwzględnienie tragicznej kondycji człowieka. Zgodnie z zestawieniem tych pojęć ze względu na ich funkcję odróżnicowania Agata Bielik-Robson zauważa, że kondycja ludzka daje się ukaz̧á́, tak jak uczynili to tragicy greccy, którzy ukazali, niczym stop-klatka, strukturę na poły nieświadomego uwikłania w sytuację; natura ludzka natomiast, która czasami uchodzi za hipostazę kondycji, wyraża się, może być studiowana i ayjaśniana (Bielik-Robson 2000: 192-224). Chrześcijaństwo, zdaniem Santayany, uwzględniło obie te lekcje, pierwszą łącząc z idea grzechu pierworodnego, a druga - z obietnica zbawienia. Założenie tych dwóch stałych to najmniej odkształcający sposób opisania potrzeby metafizycznej i wyjścia jej naprzeciw. Santayana mówi, iż w oczywisty sposób coś takiego jak „ludzka natura” „w sobie” nie istnieje, a jedynie wyraża się w ludzkiej aktywności. Można to pojęcie nazwać użytecznym psychologizmem lub zdroworozsądkową hipostazą. Na takim założeniu, zdaniem Santayany, wyrosły judaizm, a potem chrześcijaństwo. „Dążąca” natura ludzka jest brakującym „przypisem dolnym” do conditio bumana ${ }^{12}$.

Religia w XX wieku nadal oferowała się jako jedno ze „źródeł Się”, by użyć sformułowania Charlesa Taylora, choć już nie jedyne. Sekularyzacja w postracjonalnej fazie staje się więc wieloznaczna, a moralne i mądrościowe dziedzictwo tradycji religijnej może być źródłem inspiracji w sposób dający się pogodzić z oświeconą tolerancją kosmopolityzmem, a nawet ateizmem. Nowoczesne formy życia duchowego czerpią z historii praktyk duchowych bardziej lub mniej ściśle związanych z oficjalną doktryną. Wiara w „dzieje zbawienia”, życie wieczne i zmartwychwstanie domaga się korekty interpretacyjnej, która uczyniłaby je „znośnymi” prawdami dla

\footnotetext{
${ }^{12}$ Trzeba tu wyraźnie podkreślić, że Santayana jest życzliwym krytykiem, a nie bezkrytycznym apologetą chrześcijaństwa. Bronił natomiast przekonania, że „duchowość z wielu względów jest mądrzejsza od zdrowego rozsądku" (1905|1954: 267).
} 
nowoczesnego rozumu. Tylko wtedy może zachować ważność epifanii, niezależnie od rozwoju nauki. Również pojęcia wiary i duchowości w fazie postracjonalnej mogą funkcjonować autonomicznie. W późniejszych pracach Santayana rezygnuje $z$ widocznych w Life of Reason heglowskich inspiracji oraz porzuca zainteresowanie racjonalnością na rzecz coraz bardziej „prywatnej” wizji duchowości i praktycznej religijności jako zaangażowania w twórczość, miłość bądź kontemplację. Własny model kontemplacji chętnie nazywa high Platonic road, wysoka platońską ścieżką, a chrześcijaństwo staje się dlań głównie źródłem „mitycznego” dyskursu o człowieku, z którego zapożycza pojęcia „duszy”, „ducha”, „zbawienia” i „drabiny Jakubowej”. Coraz wyraźniejsza postsekularna jakość jego myśli wyraża się w przekonaniu, że myślenie posługujące się pojęciami umożliwiającymi „mapowanie” hierarchicznej struktury, nawet w momencie gdy pierwotna wiara w transcendentnego Boga i dosłowna lektura Biblii należąjuż do przeszłości, ma szansę przetrwać, wspierając konstrukcję sensu, wysiłek samodoskonalenia i pokonanie cierpienia przez podtrzymywanie naturalnego dla człowieka ruchu autotranscendencji. Taki język sprzyja aspiracji do abstrakcyjnego najwyższego dobra, zachowując „tajemnicę osiąnięcia na drodze emocjonalnej tego, co logicznie nieosiagalne" (Santayana, 1936b: 293). Forma życia uwzględniająca duchowość przejmuje legitymująca rolę widzialnej, zinstytucjonalizowanej religii. Ta należąca do postsekularnego języka wizja duchowości nawiązuje jednocześnie do fazy myślenia zwanej przez Santayanę postracjonalną.

\section{/// V.}

$\mathrm{Na}$ zakończenie powrócę do konfrontacji myślenia o religii u Santayany i Jamesa. W opozycji do perspektywy społecznej, reprezentowanej wówczas przez - dziś „,kultowego” - amerykańskiego filozofa Johna Deweya, punktem wyjścia Jamesa była indywidualna „dusza” w jej kondycji egzystencjalnej i wobec potrzeby zbawienia. Materiału do badań empirycznych dostarczyli mu zwykli ludzie, zwłaszcza uczestnicy ewangelicznych ruchów religijnych należących do dziedzictwa tzw. Drugiego Przebudzenia (Second Awakening) ${ }^{13}$, skąd pochodzi ukute przez Jamesa określenie „powtórnie urodzonych”. Choć zauważał zależność charakteru religijności od tradycji intelektualnej,

\footnotetext{
${ }^{13}$ Masowy ruch ewangeliczny w pierwszej połowie XIX stulecia, obejmujący zwłaszcza niezamożną ludność zamieszkującą na prowincji amerykańskiej, głoszący nawrócenie i zbawienie dla wszystkich, uczestnictwo oparte na spontanicznej emocjonalności, odrzucający kalwińską doktrynę predestynacji, wymóg ,uczoności” i studiowania Pisma. Pozostawił po sobie trwały ślad demokratyzacji i pluralizmu życia religijnego.
} 
James, w poszukiwaniu potwierdzenia dla hipotetycznego, pierwotnego doświadczenia religijnego, próbował przedrzeć się przez wszystkie kulturowe warstwy na nim nadbudowane. $Z$ tego względu członkowie sekt i nowych ruchów, stosunkowo mało zależnych od starych tradycji, prezentowali dlań atrakcyjna grupę badawczą. Ich zeznania miały potwierdzić jego założenie, a poszukując genezy owego doświadczenia, James odwołuje się do aktywizacji podświadomości w ramach „totalnej reakcji” na świat, która ma powodować „przesunięcie centrum energetycznego” człowieka zwane „nawróceniem” (1902|2004: 147). Choć nie problematyzuje Boga jako przedmiotu kultu, często uznaje się, że jego milczącym założeniem jest rzeczywisty kontakt $\mathrm{z}$ nadnaturalnym ${ }^{14}$.

Taylor docenił aktualność myśli Jamesa na tle sprywatyzowanej, swobodnie odniesionej do tradycji i Kościoła widzialnego rzeczywistości religijnej człowieka końca XX wieku. Postrzega wysiłek Jamesa, zmierzający ku odsłonięciu wiecznie żywych źródeł religijności ludzkiej w ich niezależnej od kultury autentyczności, jako odpowiedź na kryzys formalnych, wspólnotowych aspektów kultu. Punktując „słabości” tego ujęcia, wymienia pominięcie języka symboli i idei zawartych w tradycji religijnej oraz jej integrującej roli jako nośnika wartości i źródła tożsamości. Zarzuca Jamesowi również pominięcie Boga, co jednak wydaje się oczywista konsekwencja podejścia badacza, którego interesuje doświadczenie religijne możliwie jak najbardziej uniezależnione od teologicznych wyobrażeń. Ta życzliwa krytyka Taylora jest zgodna z elementami krytyki Santayany, który zarzuca Jamesowi zbyt daleko idący antyintelektualizm. Santayana dostrzegł u Jamesa sprzeczność między radykalnym, pragmatycznym agnostycyzmem a „apologia pewnych przesądów”, która - jego zdaniem - daje się odczytać z jego pracy (1918|1967: 76). Uważał za nieuprawnione uznanie uzyskanych przez Jamesa zeznań dotyczących często skrajnych reakcji dysydentów religijnych za reprezentatywne dla doświadczenia religijnego w ogóle. James, jego zdaniem, pominął istotę religijności, redukując ją do pewnego pierwotnego doświadczenia i eliminując czynnik intelektualny.

Różnica między Santayaną i Jamesem leży przede wszystkim w definicjach pojęć i rozłożeniu akcentów, przy czym do pewnego stopnia ich stanowiska daja się ze sobą pogodzić. Santayana rozumiał religię jako efekt pracy wykonanej przez myślenie w ramach doświadczenia świata.

\footnotetext{
${ }^{14} \mathrm{Z}$ tym odczytaniem nie zgodził się Santayana, zauważając, że jeżeli cokolwiek u Jamesa jest, to jest to samo w sobie doświadczenie oraz jego egzystencjalne skutki. Ten pogląd opierał na prywatnej znajomości z Jamesem, o którym w eseju „William James” nie bez ironii napisał: James „nie wierzył. Jedyne, w co wierzył, to prawo do wiary, że mógłbyś mieć rację, gdybyś przypadkiem uwierzył" (1918| 1967: 77).
} 
Podkreślał mediacyjną funkcję wyobraźni działającej na przecięciu racjonalnego z aracjonalnym. W sferze ducha, dzięki wyobraźni i pamięci, w ramach wspólnoty dochodzi do obiektywizacji tejże mediacji w formie religii. Źródłem sacrum dla Santayany jest świadomość w jej epifanicznym potencjale, podczas gdy dla Jamesa leży ono w doświadczeniu najgłębszej mocy witalnej. Santayana zwraca uwagę na fakt, że autonomia intelektualna wymaga oparcia w tradycji, której kontynuacja umożliwia zachowanie więzi - a tym samym uniknięcie niebezpiecznych postulatów „powrotu” do źródel - z preteoretyczną bezpośredniością, która w warunkach rosnącej złożoności kultury staje się coraz bardziej odległa od zakresu codziennego doświadczenia. Dla Santayany zatem religijność, choć ugruntowana naturalnie, jest już zawsze zapośredniczona w kulturze, podczas gdy James wierzy w możliwość spontanicznego i bezpośredniego czerpania z tych preracjonalnych źródeł właśnie za sprawą doświadczenia religijnego.

Santayana artykułuje to, czego znaczenie James umniejsza jako najmniej interesującej go „maski”, przykrywającej doświadczenie czegoś „,przemożnego". Santayana mógłby powiedzieć, że James przedziera się przez warstwę religijności i dociera do dośniadczenia præedreligijnego, czyli nagiej troski przynależącej do intencjonalnie otwartej na to-co-dane, a tym samym na nicość, ludzkiej psyche. James mówi zatem o pierwotnej mobilizacji wobec egzystencjalnego zagrożenia obcością i bezsensem. Zainteresowanie kondycją egzystencjalną i stawka, jaką jest szeroko rozumiane „zbawienie” indywidualne, są zresztą wspólne dla obu myślicieli ${ }^{15}$ (James 1902|2004: 374 i 390). Żaden z nich nie problematyzuje Boga, obaj zatrzymują się na religii i religijności jako reakcjach na doświadczenie świata, przy czym Santayanę bardziej interesuje świadomość i treści kultury, czyli sfera intersubiektywna, gdyż religijność, nawet jeśli uwarunkowana procesami nieświadomymi, wydarza sie w duchu, którego domeną jest świadomość ${ }^{16}$.

Obaj myśliciele zgodni są co do faktu, że religijność, wiążąca się z pewnym dramatyzmem, wysiłkiem i zaangażowaniem, odgrywa rolę indywidualizująca i decydująca o formie życia. Religia jest wyrazem wysiłku transcendencji faktyczności i niezgody na redukcję człowieka do banalnych wyborów dnia codziennego. Choć obaj reprezentowali pewne liberalne

\footnotetext{
${ }^{15}$ Santayana explicite mówi o najtrwalszych religiach monoteistycznych jako powstałych w odpowiedzi na najgłębszą rozpacz.

${ }^{16}$ By jednak oddać sprawiedliwość Jamesowi, należy przypomnieć, że już we wstępie do swojej książki o doświadczeniu religijnym zastrzega, iź świadom jest faktu, że jego perspektywa jest arbitralnym i kontrowersyjnym wyborem i nie wystarczy, by mówić o pełnej religii, gdyż ta obejmuje światopogląd i pewną formę racjonalności.
} 
wartości, byli też krytykami liberalizmu i prawdopodobnie nie podpisaliby się pod neopragmatyczną wizja liberalnej ironistki Richarda Rorty'ego. Z Taylorem łączy ich fakt bycia jednocześnie apologetami i krytykami nowoczesnej indywidualności.

Z pracy Jamesa można odczytać milczące przyzwolenie na okoliczność, że religijne uczucie doznawane przez znaczną część ludzkości nie jest bezprzedmiotowe i odpowiada czemuś przekraczającemu możliwości werbalizacji. Tego nie znajdziemy u Santayany, którego ateizm ostatecznie manifestuje się właśnie brakiem takiego założenia. „Boskość” u Santayany leży po stronie świadomego życia i przynależnych mu na mocy wyobraźni transcendencji ku możliwości i aspiracji ku dobru. Ta religijna predyspozycja otwiera całe spektrum postaw zaangażowania, czyli praktycznej religijności.

W ramach konkluzji należy powiedzieć, że Santayana prezentuje postracjonalne, refleksyjne podejście do religijności jako stanu świadomości ukształtowanej na bazie tradycji i do niej odniesionej. W późnej fazie twórczości skłania się ku swoistej fenomenologii duchowego doświadczenia, czyli ontologicznie uwarunkowanego sposobu bycia, przekładalnego na język kulturowo uwarunkowanych postaw. W postsekularnym geście przyznaje duchowości jako formie świadomego życia naturalny, pierwotny i autonomiczny w stosunku do religijności status. Z Jamesem łączy go przede wszystkim zyskujące coraz większą popularność w XX stuleciu uznanie, że religijność i religia pierwotnie wynikają z „totalnej reakcji” doświadczajacej świata ludzkiej sobości, a ponadto - niechęć do teokracji, świadomość potrzeby reinterpretacji kwestii religijności i religii, tak by były do pomyślenia dla nowoczesnego umysłu. Stawką jest możliwość indywidualizacji i dobro egzystencjalne, przy czym Santayana akcentuje autonomię intelektualną i rozwój duchowy czerpiące $\mathrm{w}$ interpretujący sposób z dorobku tradycji, James zaś - swoiste powtórzenie preteoretycznego „odkrycia” własnej zdolności do religijnego doświadczenia. Każdy z nich, na swój sposób, nawiązuje do niezwykle nośnego w Ameryce Emersonowskiego ideału autentyczności, co pozwala na odniesienie ich do postdurkheimowskiego paradygmatu, zgodnie z klasyfikacja Taylora. Podczas gdy James wydaje się tam zawierać „w całości”, Santayana jedynie po części, przynależąc jednocześnie do wyrastającej z XVIII stulecia kultury nazwanej przez Taylora „elitarnym humanizmem”, a przede wszystkim do antyku, za którego spadkobiercę się uważał. Jak się wydaje, dopiero postsekularny kontekst pozwala docenić nowatorski i otwierający mnogość perspektyw eklektyzm tego trudnego do zaklasyfikowania myśliciela. 
Bibliografia:

/// Berger P.L. 1969. The sacred canopy. Elements of social theory of religion, Anchor Books, New York.

/// Bielik-Robson A. 2000. Inna nowoczesność. Pytanie o wspótczesna formute duchowości, Universitas, Kraków.

/// Buczyńska-Garewicz H. 2010. Człowiek wobec losu, Universitas, Kraków.

/// Heidegger M. 2011. Bycie $i$ czas, Wydawnictwo Naukowe PWN, Warszawa.

/// James W. 2004. The varieties of religious experience, Simon \& Shuster, New York.

/// Kołakowski L. 1972. Obecność mitu, Prószyński i S-ka, Warszawa.

/// Lachs J. 1988. George Santayana, Twayne Publishers, Boston.

/// Lovely E. 2012. George Santayana's Philosopby of Religion. His Roman Catholicism and Phenomenology, Lexington Books, Plymouth.

/// Ricoeur P. 2003. Lektury i medytacje biblijne, [w:] Krytyka i przekonanie, KR, Warszawa, s. 99-243.

/// Santayana G. 1936a. Interpretations of Poetry and Religion, [w:] The Works of George Santayana, t. II, Triton edition, Charles Scribner's Sons, New York, s. 3-201.

/// Santayana G. 1936b. The Ultimate Religion, [w:] Obiter Scripta, Charles Scribner's Sons, New York, s. 280-297.

/// Santayana G. 1942. Realms of Being, Charles Scribner's Sons, New York. /// Santayana G. 1954. The Life of Reason, Charles Scribner's Sons, New York.

/// Santayana G. 1967. William James, [w:] Character and opinion in the United States, The Norton Library, New York, s. 64-96.

/// Santayana G. 1968. The German Mind: a Philosophical Diagnosis, Apollo Editions, New York.

/// Santayana G. 1998. The Genteel Tradition. Nine Essays by George Santayana, red. D.L. Wilson, University of Nebraska Press, Lincoln.

/// Simmel G. 1923. Goethe, Klinkhardt \& Biermann, Lipsk. 
/// Stone J.A. 2008. Religious Naturalism Today: The Rebirth of a Forgotten Alternative, State University of New York Press, New York.

/// Taylor C. 1989. The Sources of the Self: The Making of Modern Identity, Cambridge University Press, Cambridge.

/// Taylor C. 2002. Oblicza religii dzisiaj, tłum. A. Lipszyc, Znak, Kraków.

/// Taylor C. 2003. Varieties of Religion Today: William James Revisited, Harvard University Press, Harvard.

\section{/// Abstrakt}

George Santayana był filozofem, krytykiem kultury i ateistą żywo zainteresowanym religia, a także adwokatem teorii o naturalnym ugruntowaniu ludzkiej duchowości, której zapoznanie zarzucał nowoczesnym formom życia. Odwołania do tekstów z różnych okresów jego twórczości w konfrontacji z myślą Williama Jamesa, Petera Bergera czy Charlesa Taylora mają na celu uwypuklenie postsekularnych wątków jego myślenia o religii i wykazanie, że to właśnie one zapewniają tej nowatorskiej myśli jedność. Ukute przez Santayanę określenie postracjonalności sprowadza się do przekonania, że myślenie odniesione do pewnej tradycji i posługujące się pojęciami umożliwiającymi odtwarzanie pewnej struktury sprzyjającej pożądanym formom świadomego życia, nawet w momencie gdy naiwna wiara i tradycyjne formy religijności się wyczerpały, ma szansę przetrwać, wspierając konstrukcję sensu, wysiłek samodoskonalenia i radzenie sobie z cierpieniem przez podtrzymywanie naturalnego dla człowieka ruchu autotranscendencji.

Słowa kluczowe:

duchowość, postsekularyzm, racjonalność, rozum instrumentalny, religia

\section{/// Abstract}

George Santayana - a philosopher, a critic of culture and an atheist deeply concerned with the issue of religion and secularization was an advocate of the idea of naturally founded human spirituality. Hence his critique of some modern forms of life which in his view were guilty of spiritual ignorance and the flattening of language. This essay, by juxtaposing Santayana's ideas with those of William James, Peter Berger and Charles 
Taylor, aims at revealing some postsecular aspects of his thinking about religion and the unity they introduce into the large body of his eclectic writing. Santayana's understanding of post-rationality commences in the idea that thinking rooted in a certain tradition and operating with certain terms allows for maintain a living mental structure which provides a favorable ground for spiritual growth and existential meaningfulness even after conventional forms of religiosity have faded.

Keywords:

spirituality, postsecularism, rationality, instrumental thinking, religion 